УДК $316.6+159.98$

Здоровенко Наталія Вікторівна, практичний психолог вищої категорії СЗОШ «Надія»,02000,вул.Янгеля,2, м.Київ,Україна;zdor_nat@ukr.net;+38(067)255-04-44 ORCID ID 0000-0002-6636-7628

Коляденко Ніна Володимирівна, доктор медичних наук, доцент, завідувач кафедри загальномедичних дисциплін i психосоматики ПрАТ «ВНЗ «Міжрегіональна Академія управління персоналом», 02000, вул. Фрометівська, 2, м. Київ, Україна; nina-k@ukr.net;+38(067)756-72-57

ORCID ID 0000-0003-2099-0163

\title{
АВТОРСБКА КОРЕКЦІЙНО-РОЗВИТКОВА ПРОГРАМА «УМОВИ \\ ТА ТЕХНОЛОГІЇ ФОРМУВАННЯ СОЦІАЛЬНОЇ КОМПЕТЕНТНОСТІ ПІДЛІТКІВ»
}

\begin{abstract}
Анотація
Здоровенко Н. В., практичний психолог вищої категорії СЗОШ «Надія», Київ, Україна; Коляденко Н. В., доктор медичних наук, доцент, завідувач кафедри загально медичних дисциплін і психосоматики ПрАТ «ВНЗ «МАУП», Київ, Україна. Авторська корекційно-розвиткова програма «Умови та технології формування соціальної компетентності підлітків».

Ключові слова: соціальна компетентність підлітків, корекційнорозвиткова програма.

Постановка проблеми. В умовах розбудови освіти в Україні надзвичайно актуальною є проблема формування соціальної компетентності учнів старших
\end{abstract}


класів школи, що зумовлено пошуком оптимальних шляхів підготовки їх до самостійного життя.

Аналіз останніх досліджень і публікацій. Процес включення особистості в соціальні структури і ступінь його ефективності привернули увагу науковців порівняно недавно. На початку XX ст. тільки вводиться термін «соцальний інтелект», подальші заглиблення в тему виокремлюють поняття компетентності. На даний час не існує єдиної усталеної думки щодо поняття «соціальна компетентність» - у зміст та структуру терміна різні автори вкладають своє трактування та складові, що дає перспективи для подальшої розробки теми. В основному, науковці розглядають соціальну компетентність в ракурсі успішної адаптації особистості в соціумі, через адекватне застосування особистісних якостей та вміння приймати усталені норми, правила, що висуваються сусільством.

Формулювання мети статті. Метою є презентація авторської програми корекційно-розвиткової програми формування соціальної компетентності підлітків, спрямованої на розвиток соціальної компетенції учасників через використання принципів диференційованого підходу в оцінюванні соціуму 3 урахуванням ієрархічності та вмінням ранжування інформації, подій, оточення, потреб, що, в свою чергу, стане основою для формування соціальнозрілої особистості, яка по закінченню навчального закладу зможе з високим рівнем вірогідності максимально адаптуватися в соціумі, адекватно реагуючи на його зміни, планувати власне майбутнє - як професійне, так і особисте, створити родину і зайняти своє місце в суспільстві, самореалізуватися, набувати та вдосконалювати необхідні для цього навички, використовуючі природні дані.

Виклад основного матеріалу. Програма, враховуючи фактори впливу соціуму, спрямована на формування критичності i реалістичності світосприйнятт, адекватності в поведінці відповідно ситуації, 
самоідентифікації себе та свого місця в житті, що є основою формування соціальної компетентності. Вона містить ряд ідей, реалізованих у тематичних заняттях для учнів старших класів, спрямованих на нівеляцію негативних наслідків впливу факторів соціального середовища, що призводять до викривлення світосприйняття. Проведення роботи за даною програмою стимулює розвиток соціального інтелекту, як основи для надбання соціальної компетентності, дозволяє отримати позитивні результати в напрямку соціалізації та адаптації майбутнього покоління.

Висновки та перспективи подальших досліджень. Застосування програми дозволяє підвищити навчальний інтерес учнів, а відтак і якість їх знань, вмінь, навичок, які вони здобуватимуть в процесі навчальної діяльності. Спільна робота, опанування основ тематичної дискусії з дотриманням етичних норм, сприяє підвищенню рівня вихованості дітей, їх емпатійності, позитивній комунікативності.

\section{Аннотация}

Здоровенко Н. В., практический психолог высшей категории СОШ «Надежда», Киев, Украина; Коляденко Н. В., доктор медицинских наук, доцент, заведующий кафедрой общих медицинских дисциплин и психосоматики ЧАО «ВУЗ «МАУП», Киев, Украина. Авторская коррекционно-развивающей программа «Условия и технологии формирования социальной компетентности подростков».

Ключевые слова: социальная компетентность подростков, коррекционно-развивающей программа.

Постановка проблемы. В условиях развития образования в Украине чрезвычайно актуальной является проблема формирования социальной компетентности учащихся старших классов школы, что обусловлено поиском оптимальных путей подготовки их к самостоятельной жизни. 
Анализ последних исследований и публикаций. Процесс включения личности в социальные структуры и степень его эффективности привлекли внимание ученых сравнительно недавно. В начале XX в. только вводится термин «соцально интеллект», дальнейшие погружения в тему выделяют понятие компетентности. В настоящее время не существует единой устоявшейся мысли относительно понятия «социальная компетентность» - в содержании и структуре термина разные авторы вкладывают свою трактовку и составляющие, дает перспективы для дальнейшей разработки темы. В основном, ученые рассматривают социальную компетентность в ракурсе успешной адаптации личности в социуме, через адекватное применение личностных качеств и умение принимать устоявшиеся нормы, правила, предъявляемые сусильством.

Формулировка цели статьи. Целью является презентация авторской программы коррекционно-развивающей программы формирования социальной компетентности подростков, направленной на развитие социальной компетенции участников из-за использования принципов дифференцированного подхода в оценке социума с учетом иерархичности и умением ранжирование информации, событий, окружение, потребностей, что, в свою очередь, станет основой для формирования социальнозрилои личности, по окончании учебного заведения сможет с высоким уровнем достоверности максимально адаптироваться в социуме, адекватн реагируя на его изменения, планировать собственное будущее - как профессиональное, так и личное, создать семью и занять свое место в обществе, самореализоваться, приобретать и совершенствовать необходимые для этого навыки, использующие природные данные.

Изложение основного материала. Программа, учитывая факторы влияния социума, направленная на формирование критичности и реалистичности мировосприятие, адекватности в поведении соответственно 
ситуации, самоидентификации себя и своего места в жизни, что является основой формирования социальной компетентности. Она содержит ряд идей, реализованных в тематических занятиях для учащихся старших классов, направленных на нивелирование негативных последствий влияния факторов социальной среды, приводящие к искажению мировосприятия. Проведение работы по данной программе стимулирует развитие социального интеллекта как основы для достижения социальной компетентности, позволяет получить положительные результаты в направлении социализации и адаптации будущего поколения.

Выводы и перспективы дальнейших исследований. Применение программы позволяет повысить учебный интерес учащихся, а следовательно и качество их знаний, умений, навыков, которые они будут получать в процессе учебной деятельности. Совместная работа, овладение основами тематической дискуссии с соблюдением этических норм, способствует повышению уровня воспитанности детей, их эмпатийности, положительной коммуникативности.

\section{Annotation}

Zdorovenko NV, practical psychologist of the highest category of "Nadiya" Secondary School, Kyiv, Ukraine; Koliadenko NV, PhD, MD, Associate Professor, Head of the Department of General Medical Disciplines and Psychosomatics, The Private Joint-Stock Company "Higher Educational Institution "Interregional Academy of Personnel Management", Kyiv, Ukraine. Author's Correctional and Developmental Program "Conditions and Technologies for the Formation of Social Competence of Adolescents."

Key words: social competence of adolescents, correctional and developmental program. 
Formulation of the problem. In the context of the development of education in Ukraine, the problem of forming the social competence of high school students is extremely relevant, which is due to the search for optimal ways to prepare them for independent living.

Analysis of recent research and publications. The process of inclusion of the individual in social structures and the degree of its effectiveness have attracted the attention of scientists relatively recently. In the early twentieth century. only the term "social intelligence" is introduced, further immersions in the topic distinguish the concept of competence. Currently, there is no single opinion on the concept of "social competence" - in the content and structure of the term, various authors invest their interpretation and components, which gives prospects for further development of the topic. Basically, scientists consider social competence in the perspective of successful adaptation of the individual in society, through the adequate use of personal qualities and the ability to accept established norms, rules put forward by the neighborhood.

Formulating the purpose of the article. The aim is to present the author's program of correctional and developmental program of social competence of adolescents, aimed at developing social competence of participants through the use of differentiated approaches in assessing society, taking into account hierarchy and ranking skills, events, environment, needs, which, in turn, will be the basis for the formation of a socially mature personality, which after graduation will be able with a high level of probability to adapt as much as possible in society, adequate reacting to its changes, plan their own future - both professional and personal, a family, and take their place in society, self-realization, to acquire and improve the necessary skills using natural data.

The presentation of the main material. The program, taking into account the factors influencing society, aims to form a critical and realistic worldview, adequacy in behavior according to the situation, self-identification of themselves and their place 
in life, which is the basis for the formation of social competence. It contains a number of ideas implemented in thematic classes for high school students, aimed at eliminating the negative effects of social factors that lead to a distortion of worldview. Carrying out work on this program stimulates the development of social intelligence as a basis for the acquisition of social competence, allows to obtain positive results in the direction of socialization and adaptation of the future generation.

Conclusions and prospects for further research. The application of the program allows to increase the educational interest of students, and hence the quality of their knowledge, skills, abilities, which they will acquire in the process of educational activity. Working together, mastering the basics of thematic discussion in compliance with ethical norms, helps to increase the level of education of children, their empathy, positive communication.

Ключові слова: соціальна компетентність підлітків, корекційнорозвиткова програма.

Постановка проблеми. В умовах розбудови освіти в Україні надзвичайно актуальною є проблема формування соціальної компетентності учнів старших класів школи, що зумовлено пошуком оптимальних шляхів підготовки їх до самостійного життя. В школі, як міні-моделі суспільства, діти мають можливість усвідомити, а в ідеалі, зрозуміти і прийняти, основні принципи суспільного співіснування, роботи і взаємозв'язку ієрархічних підструктур, їх ролі та функції. Важливим моментом $є$ самоідентифікація в цій структурі зі своєю роллю, усвідомлення прав, обов'язку, відповідальності. Не можна недооцінювати роль і силу впливу педагогів на формуванні життєвих цінностей, соціальних, комунікативних та інших компетенцій майбутнього покоління. 
Окреслимо очевидні і найбільш значущі проблеми психологічного і морального характеру, що стають перепоною на шляху адекватного включення підростаючого покоління в соціум:

- Викривлене розуміння свого місця в соціумі, коло «права-обов'язкивідповідальність» викривлене в бік прав. Як наслідок - довготривала інфантильність, прикрита фразеологічними штампами, що створюють іллюзію розумності;

- Заміна знань і дій на емоції. Пошук шляхів отримання позитивних емоцій без докладання зусиль. Підміна діяльності, спрямованої на довгострокову перспективу (з виходом на відчуття задоволення від роботи) на швидкі кроки, що дозволяють отримати позитивні емоції в даний момент.

- Підміна адекватності в реальності на популяризаційні штампи. Зменшується кількість позитивних, конструктивних, високоморальних взірців образу сучасної людини в телемедійному просторі, які могли б стати взірцем для підлітків. Суть замінюються на оболонку, незвичайність, яскравість і ексцентричність якої гіпнотично діє на нестійку психіку. Роль сімї як взірця адекватності і констуктивності зменшується.

- Недиференційоване сприймання інформаційного потоку, заміна раціонального підходу на емоційний. Поняття «добре» i «погане» формуються в чуттєвій сфері егоцентризму.

- Слабке розуміння структурності, масштабності, ієрархічності, підпорядкованості, взаємозалежності, починаючи від найближчого оточення i до міжнародного та вищих рівнів. Відтак, нечітке усвідомлення ролей і виконання відповідних функцій кожного з учасників взаємодій.

Аналіз останніх досліджень і публікацій. Процес включення особистості в соціальні структури і ступінь його ефективності привернули увагу науковців порівняно недавно. На початку XX ст. тільки вводиться термін «соцальний 
інтелект», подальші заглиблення в тему виокремлюють поняття компетентності. На даний час не існує єдиної усталеної думки щодо поняття «соціальна компетентність» - у зміст та структуру терміна різні автори вкладають своє трактування та складові, що дає перспективи для подальшої розробки теми. В основному, науковці розглядають соціальну компетентність в ракурсі успішної адаптації особистості в соціумі, через адекватне застосування особистісних якостей та вміння приймати усталені норми, правила, що висуваються сусільством $[2 ; 3 ; 6-9]$

Питання сутності, змісту та структури соціальної компетентності особистості у вітчизняній науці недостатньо розроблені. В Україні означеній проблемі присвячена недостатня кількість досліджень [2; 6]. Узагальнюючи теоретичні розробки та практичні надбання, зупинимось на трактовці, яка дає найбільш повну характеристику даного поняття.

Соціальна компетентність - базисна, інтегральна характеристика особистості, що відображує ii здатність ефективно взаємодіяти 3 іншими людьми, забезпечує повноцінне оволодіння соціальною реальністю і дає можливість ефективно вибудовувати свою поведінку та вирішувати типові проблеми і задачі, що виникають в реальних ситуаціях повсякденного життя у відповідності з прийнятими в соціумі на даний момент нормами й цінностями. Вона формується в ході освоєння індивідом систем спілкування та включення в спільну діяльність, і досягається через актуалізацію соціального інтелекту. Завдяки цій здатності людина може моделювати і оцінювати наслідки своїх дій наперед і на довгострокову перспективу [2; 6].

До складу соціальної компетентності входять: уміння орієнтуватись в соціальних ситуаціях; уміння правильно оцінювати особистісні особливості та емоційні стани інших людей; уміння обирати адекватні засоби спілкування і поводження 3 людьми, реалізовувати їх в процесі взаємодії. Поведінка 
особистості в соціумі зумовлюється та мотивується багатьма чинниками: особливостями розвитку суспільства; способами розв'язання суперечностей; механізмами реалізації соціального життя; соціальними та індивідуальними умовами життєвої ситуації; особливостями соціальної інфраструктури; засвоєними традиціями, звичаями й життєвими цінностями. Важливу роль відіграє «Я-концепція» особистості, взаємозв'язок якої з соціальним життям полягає в досягненні гармонії з оточенням, в його підтримці. Отже, йдеться про свідому оцінку людиною своїх дій і вчинків, прийняття (або неприйняття), зміну, корекцію стереотипів, цінностей відповідно до норм суспільства $[2 ; 6]$.

Формування соціальної компетентності школярів проходить безперервно і в тому оточенні, в якому вони знаходяться. Але існує ряд психологічних проблем, які стають суттєвою перепоною і стримуючим фактором на шляху їх реалізації. Вони сформувалися як результат впливу факторів зовнішнього середовища на незрілу емоційно-вольову сферу підлітків. Максималізм, притаманний підліткам, схильність до ексцентричності позбавляють їх можливості реально і критично оцінювати потік інформації. В них не сформовані психологічні структури, які б дозволяли їм розподіляти ці потоки, оцінювати і адекватно пристосовувати в своєму житті. Оцінювання проходить за принципом - «це мені подобається, це не подобається». Не маючи уявлення про певний предмет, явище, не маючи досвіду в певній справі чи сфері, вони намагаються висловлювати свою думку. I ця «думка» зводиться приблизно до рівня «це погано, тому, що мені не подобається, а це добре, бо мені подобається». Тобто, реальність підмінюється на емоційність. Інфантильність, як слідство гіпертрофування прав 3 мінімалізацією чи повною відсутністю обов'язків, акцент на зовнішній локус-контроль і зосередженість на власній емоційності, віідсутність адекватної оцінки стимулюють вибір на користь дій, кроків і подій, що принесуть «позитив», хоч і швидкоплинучий. Втрачається 
усвідомлення важливості реальних результатів, досягнення яких пов'язано, як правило, $з$ подоланням труднощів, і що найголовніше - 3 можливими негативними емоціями [6;8].

Егоцентризм, притаманний віку, підтримується і вкорінюється в структурі особистості підлітків насамперед через підміну реальності на віртуальність в соцмережах. Слаборозвинена критичність не дає можливості адекватно оцінювати ні себе, ні оточення. Відповідно, не можна говорити про планування свого майбутнього, про адекватність при включенні в соціальні структури, оскільки про них немає реального уявлення $[4 ; 5 ; 11 ; 12]$.

Школа, поряд з родиною, відіграє суттєву роль у формуванні соціальної компетентності. Відбувається співпраця, конкуренція, комунікація з різними віковими групами. Усвідомлюються початкові поняття соціальної ієрархії, соціального статусу: від техперсоналу до директора. Починається процес самоідентифікаціі, відбувається пошук та усвідомлення своєї ніші [10].

Сімейно-родове коло стимулює навчання вирішенню питань побутовоекономічного характеру з урахуванням людського фактору. Засвоюються способи вирішення конфліктів, на фоні емоційно-емпатійного спілкування [5; 8 ; $10]$.

Громадські місця (лікарні, транспорт, зупинки транспорту, дорога, торгові точки, інше) дають можливість засвоїти вирішення проблем побутового чи економічного характеру [1]. Характер проблем схожий із сімейними, але в оточенні переважають чужі люди. Відбувається навчання дистанції, пієтету, емоційній стриманості.

Кіно дає зразки образів і поведінки [1]. Звісно, перевага надається Героям - позитивним чи негативним, але вони так чи інакше мають вражати, тобто вибиватись із загального фону (одяг, манери, емоційність, бунтарство, харизма). Ток-шоу: ті самі побутові проблеми, які вже знайомі. Пропонуються шляхи їх 
вирішення: раціональні, емоційні, комунікаційні, інші. Пізнавальні передачі: розширення наукової сфери, освоєння якої започаткувала школа. Накопичення знань про оточуючий світ, можливо спроба диференціювати інформацію. Розважальні передачі: емоційна сфера (плюс комунікативна, емпатийна). Політичні передачі і новини: розширяють політичне бачення, дають розуміння взаємозалежності на різних рівнях - від особистостей до міжнародних відносин.

Реклама,- будучи джерелом інформації в певній сфері, вона $є$ носієм емоційності, як правило агресивного характеру, 3 використанням речень спонукального типу. Саме ця емоційність і спонукання тисне на дитячу свідомість, реклама стає не просто інформацією, а претендує на зразки поведінки, пропонує певний стиль життя. Наслідування стереотипів, стилі, форми поведінки, життєві цінності.

Соціальні мережі,- для більшості підлітків вони стають життєзамінниками. Ілюзія свободи в поведінці: незалежності (від дорослих, правил, обов'язків), безкарності, безвідповідальності. Ілюзія позитивних емоцій: спілкування, належності до референтної групи, поваги, власної значимості. Зазначені фактори створюють ілюзію психологічного комфортного середовища. не дивно, що там хочеться перебувати.

Зворотна сторона віртуального світу - психологічний інфантилізм із відсутністю відповідальності за свої вчинки, агресивність або емоційна холодність, певне звуження кругозору, ризик асоціальної поведінки. Навряд чи можна говорити про соціалізацію особистості через використання соцмереж Інтернету: скоріше мова йде про перенавчання, пристосування до реалій соціума після виходу з віртуального комфорту, що певною мірою складніше, ніж навчання з початкового рівня.

Враховуючи вищесказане, ми розробили корекційно-розвиткову програму формування соціальної компетентності підлітків. 
Формулювання мети статті. Метою є презентація авторської програми корекційно-розвиткової програми формування соціальної компетентності підлітків, спрямованої на розвиток соціальної компетенції учасників через використання принципів диференційованого підходу в оцінюванні соціуму 3 урахуванням ієрархічності та вмінням ранжування інформації, подій, оточення, потреб, що, в свою чергу, стане основою для формування соціальнозрілої особистості, яка по закінченню навчального закладу зможе з високим рівнем вірогідності максимально адаптуватися в соціумі, адекватно реагуючи на його зміни, планувати власне майбутнє - як професійне, так і особисте, створити родину і зайняти своє місце в суспільстві, самореалізуватися, набувати та вдосконалювати необхідні для цього навички, використовуючі природні дані.

Виклад основного матеріалу. Програма є результатом роботи над ідеєю, що лежить в основі як психології, так і педагогіки - формування адекватних, позитивно налаштованих членів соціуму, які володіють життєвими компетенціями (комунікативними, емпатійними, соціальнми, т.п.), здатні працювати як самостійно так і в колективі, планувати і вибудовувати майбутнє як власне, так і суспільне. Вона містить ряд ідей, реалізованих у тематичних заняттях для учнів старших класів, спрямованих на нівеляцію негативних наслідків впливу факторів соціального середовища, що призводять до викривлення світосприйняття. Програма, враховуючи фактори впливу соціуму, спрямована на формування критичності і реалістичності світосприйняття, адекватності в поведінці відповідно ситуації, самоідентифікації себе та свого місця в житті, що є основою формування соціальної компетентності.

\section{Завдання програми:}

- підвищити рівень соціального інтелекту, який є основою для формування соціальної компетентності, розширити кругозір, навчити структурності при обробці отриманої інформації; 
- спрямувати свідоме сприйняття оточення на раціональне бачення, виробити звичку до диференціації інформаційного потоку, спрямувати свідомість в бік об’єктивного оцінювання (себе, людей, ситуацій, подій);

- збільшити ступінь адекватності дій, через усвідомлення причиннонаслідкових відношень подій;

- сформувати поняття кордонів, дистанцій між людьми в колах спілкування, між різними сферами життя, серед соціальних структур;

- навчити складати логічну картину існування світу, розуміти місце окремих структур, їх ієрархічність та їх взаємопов'язаність, місце і роль окремих людей в кожній з них;

• відпрацювати комунікативні навички;

- виробити звичку до співпраці як діяльності, що 3 мінімальними енергетичними витратами дозволяє досягнути результатів.

Методи: аналіз, синтез, контент-аналіз, рефреймінг.

Форма проведення роботи: міні-семінари, міні-тренінги.

Tехніки: обговорення, дискусії, мозковий штурм.

\section{Опис програми}

В програмі використовується прийом комбінативного співставлення, 3 аналізом природи людини в центрі як основа: горизонтальний та вертикальний зрізи. Горизонтальний - включеність людини в кола спілкування, соціальні структури, її роль в кожному з них. Вертикальний - дослідити зміни окремої особистоті 3 плином часу, визначити вікові категорії (на свій розсуд, 3 грунтовною аргументацією), визначити роль і функції людини на кожному віковому етапі. Порівняти ролі і функції кожної вікової категорії. Одночасно ставиться задача проаналізувати потреби людей в кожний історичний період, використовуючи піраміду ієрархій потреб 3 урахуванням історичних особливостей - політичних, економічних, медичних, наукових. Прослідкувати 
за історичними змінами в людському суспільстві. Порівняти ціннісні орієнтації суспільства в історичному аспекті та в особистому плані. Які рівні піраміди співпадають, які кардинально відрізняються? Зробити висновки. На фінальній стадії психолог (педагог) має допомогти учням узагальнити всю отриману і проаналізовану ними інформацію, і акцентуватися на таких моментах: людина залишається людиною і в сучасності, і 1000 років до цього, 3 тими самими потребами: досягнення науки і техніки, нова мода не роблять людину іншою (ті самі руки, ноги, інші частини тіла), іiі особисті потреби не міняються; на кожному віковому етапі є своя роль, права, обов'язки, відповідальність: у дітей більше прав, у дорослих - відповідальності; кожен елемент означеного ланцюга має свої межі - твої права закінчуються там, де починаються права іншого. I найголовніше - підкреслити взаємозв'язок всіх людей, і як окремих індивідів, i як таких, що включені в певну соціальну структуру.

Передбачено поступове розширення кругозору учасників 3 активними мисленєвими діями: аналіз, синтез, умовиводи. Теми, підібрані для роботи, стимулюють актуалізацію соціального інтелекту 3 перспективою розвитку соціальної компетентності і розкриваються поступово, крок за кроком. Всі заняття, включені в програму, розбиті на тематичні блоки, що проводяться в хронологічному порядку.

- Перший блок. Задача його - дати учасникам поняття структури людського сусільства, допомогти зрозуміти природу розподілу людей на групи та, для самоусвідомлення себе як частини людського колективу, кола спілкування (рис. 1). Роз'яснити диференціацію функцій учасників кожного кола, аргументувати різницю в поведінці особистості для кожного $з$ кіл. Дати поняття: «друг - знайомий - незнайомець». Показати взаємовключеність кіл, вззаємозв'язок як всередині кожного з них, так і між ними. Зробити акцент на людському факторі власного оточення. Розраховано на 3 заняття. 


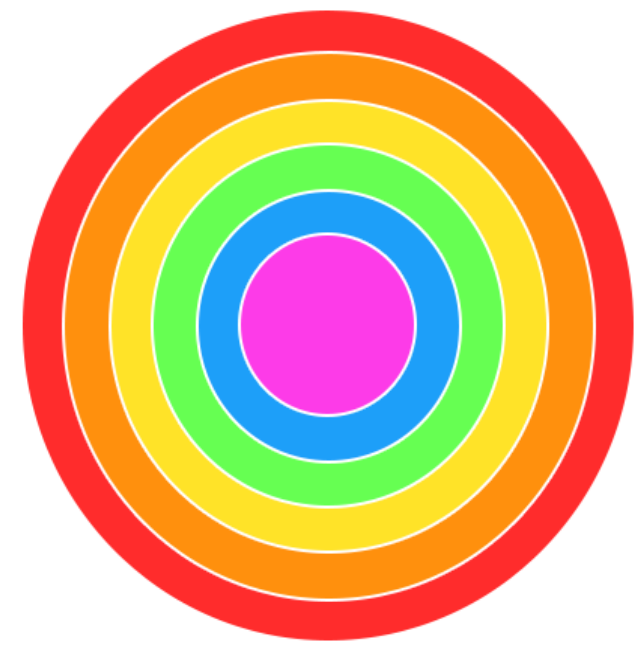

\section{Я. Мій особистий простір}

\section{Родина}

Друзі

\section{Знайомі}

\section{Професійна допомога}

\section{Незнайомі}

Рис. 1. «Кола спілкування» (соціальні кола)

- Другий блок. «Коло життя» (рис. 2). Завдання цього блоку - окреслити сфери діяльності в житті людини. Спочатку навчити розмежуванню таких понять, як робота, відпочинок, навчання тощо, підштовхнути до розуміння, що кожен крок, дію чи бездіяльність можна віднести до відповідної категорії. Потім визначити ієрархічність відповідних сфер. Розробці теми присвячено 2 заняття.

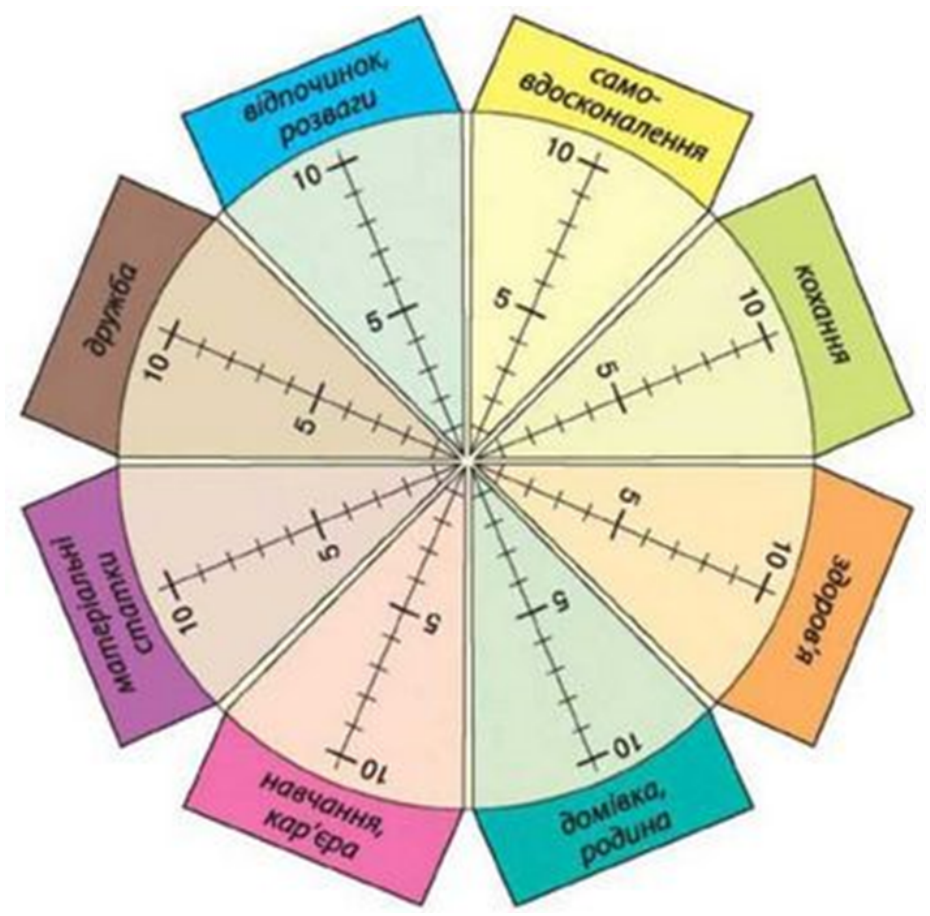

Рис. 2. Схема «Колесо життя» 
- Третій блок. Ієрархія потреб (рис. 3). Продовження попередньої теми. Використовуючи піраміду Маслоу, розширити рамки простої констатації. Визначити ролі і функції оточення, а також - особливо - власні, на кожному рівні. Розраховано на 2 заняття.

- Четвертий блок. Структура людського суспільства. Продовження i розширення попередньої тематики. Використовуючи набуті в процесі навчання історико-географічні знання, телемедійну інформацію, власний досвід i спостереження, скласти соціальну структуру суспільства різних історичних періодів на різних територіях, різних народностей. Прослідкувати історичні зміни в складі структур. Скласти їх ієрархію за ступенем пріоритетності, важливості на кожному етапі. Виокремити функції кожної. Порівняти. Дати оцінку. Розраховано на 3 заняття.

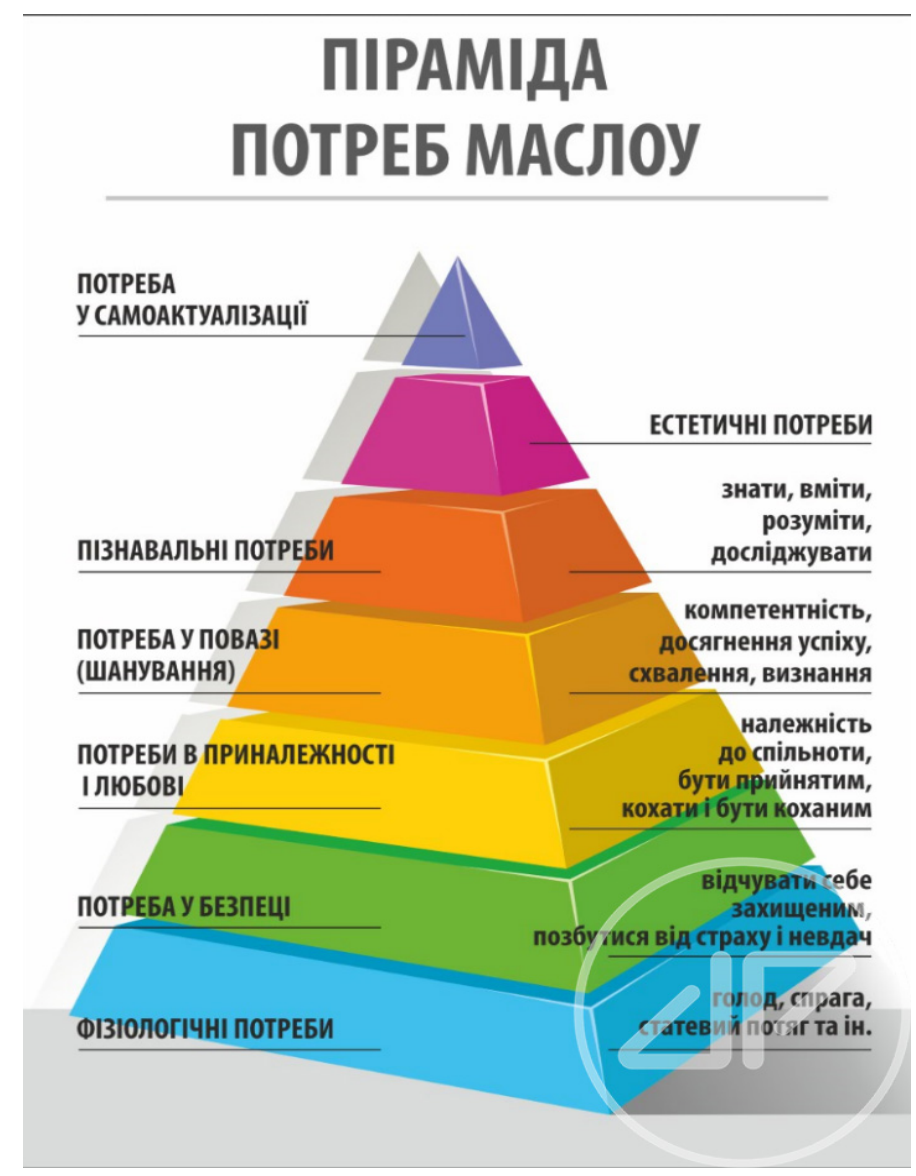

Рис. 3. Ієрархія потреб Маслоу 
- П’ятий блок. Критичність мислення. Навчити учасників диференційованому підходу в оцінюванні інформаційного потоку 3 використанням контент-аналізу. Дати розуміння комплексності отримуваної інформації та показати принципи іiі диференціації: інформаційна, емоційна, естетична, енергетична та інші складові. Вплив та види ефектів, що супроводжують інформацію: візуальні, аудіальні, інші. Для практики даємо домашні завдання, обговорення результатів - спільно, на заняттях. Розраховано на 4 заняття.

- Шостий блок. Природа людини. Проводяться горизонтальний та вертикальний зрізи. Горизонтальний - включеність людини в кола спілкування, соціальні структури, іiї роль в кожному з них. Вертикальний - дослідити зміни окремої особистоті з плином часу, визначити вікові категорії, роль і функції на кожному часовому етапі. Порівняти. Прослідкувати за історичними змінами в людському суспільстві. Порівняти ціннісні орієнтації суспільства в історичному аспекті та в особистому плані. Застосувати піраміду ієрархії потреб для аналізу. Розробці теми присячено 2 заняття.

\section{Приклади роздаткового матеріалу - інструкції до міні-сценок}

I. Ремонт. Квартира 3-кімнатна. Ремонт проводиться по черзі в кожній з них. Мешканці: бабуся, мама, тато, 2 брати, кіт.

Проблема 1. Де, в якій комбінації розміститися під час ремонту в одній 3 кімнат.

Проблема 2. Вибір шпалер для всіх кімнат.

Проблема 3. Фронт робіт для кожного учасника - ремонт робимо своїми силами.

Бабуся: не хоче переходити в іншу кімнату; не любить шум; обирає пастельний колір шпалер. 
Тато: не знаходить спільної мови з бабусею, надає перевагу сірим тонам, важко переносить присутність кота.

Мама: хоче усі кімнати зробити в одному стилі, квіткові шпалери.

Брат Сашко: фанат раллі, хоче кімнату відповідно облаштувати.

Брат Федір: майбутній науковець, хоче бачити на стінах формули і закони фізики.

Кіт: товариський, не переносить самотності, дуже балакучий, плутається під ногами коли не спить.

II. Виїзд на природу. Сімейний відпочинок: Виїзд на природу з ночівлею. Родина: бабуся, мама, тато, брат, сестра, собака, машина.

Проблема 1. Вибір: берег річки, ліс, гори.

Проблема 2. Збори: що брати з собою.

Проблема 3. Як дістатись місця: своєю машиною, міським транспортом, пішки, інші варіанти.

Тато: надає перевагу горам, береже машину.

Мама: хоче на річку, на своїй машині, всією родиною

Брат: без товариша не хоче нікуди їхати

Сестра: не може без інтернета і душа

Бабуся: мудра, миролюбна людина, любить спокій

III. Територія лікарні. Ролі: пацієнт, медична сестра, санітарка, лікар, депутат, електрик, міністр.

IV. Кав'ярня. Ролі: відвідувач, офіціант, повар, сантехнік, охоронець, директор кав’ярні, естрадна зірка, грузчик, директор цирку.

V. Автобус. Ролі: пасажири (3-4), кондуктор, водій, контролер, депутат, полісмен, дідусь із втратою пам'яті.

VI. Зоопарк. Ролі: директор зоопарку, касир, директор овочебази, відвідувачі (2-3), охоронець, балувана дитина. 
VII. Школа. Ролі: Учні (3-4), вчитель, директор, президент, прибиральниця, сантехнік, садівник, лікар.

\section{Варіанти проблемних (чи просто побутових) ситуацій:}

- Ситуація 1. Закінчилась їжа. Треба вирішити це питання.

- Ситуація 2. Ви граєтесь, один з дітлахів упав, плаче, не піднімається, тримається за ногу. Що робити?

- Ситуація 3. Ви в людному місці і ваш товариш почав дивно поводитись: впав, його бьють судоми, закотив очі, не відповідає на ваші питання. Що може відбуватись далі?

- Ситуація 4. Крадіжка в торговому місці. С свідки. Злодія впіймали. Як будуть розвиватися події?

- Ситуація 5. Поряд 3 вами поселилася родина, в якій є дуже вродлива дівчина. Наступного дня у вас хтось сильно захворів, не встає 3 ліжка, не їсть, т.і. Який імовірний розвиток подій?

- Ситуація 6. Холодна пора року. В помешканні не жарко. Як вирішити проблему?

- Ситуація 7. Ви - з дороги, а води нема. Як бути?

- Ситуація 8. Вам треба повідомити бабусю про (...). Напишіть записку. Відправте повідомлення.

- Ситуація 9. Ви отримали домашне завдання 3 біології, географії, математики, письма. Яким воно може бути і як його виконати?

- Ситуація 10. Ви на березі, вам необхідно на інший бік. $Є$ певні перепони. Які вони? I як можна вийти з ситуації?

В програмі просуваються та втілюються ідеї, що дозволяють людині не просто прилаштуватися та використати складові компоненти соціуму (матеріальні та моральні) для знаходження свого комфортного місця в ньому, а й обрати своє місце та виконувану в ньому роль із розумінням та усвідомленням 
ієрархічності структури та зв'язків між ії компонентами, що передбачає високу оптимальність та результативність в діяльнісній i поведінковій сферах. Технології програми спрямовані на стимуляцію розширення світогляду особистості: на бачення і усвідомлення ієрархічності структур (від мініколективу до планетарного масштабу), їх взаємовключеності та взаємодії, ролей кожної з них та власну роль. Таке бачення дозволяє 3 великим ступенем вірогідності прогнозувати дії (оточуючих і власні), передбачати наслідки, приймати дійсність і адекватно реагувати на соціально-психологічні подразники та непередбачені події. Бачення, розуміння та усвідомлення більшої кількості компонентів, а відтак і більшої кількості варіантів взаємодій дозволяє віднайти і реалізувати різні варіанти включення в соціум з максимальною ефективністю.

Основна точка спрямування тематики занять - підвищення рівня соціального інтелекту, який $\epsilon$ основою для формування соціальної компетентності. В результаті роботи в учасників виробляється раціональне бачення, звичка до диференціації інформаційного потоку, вдосконалюються комунікативні навички. Проведення роботи за даною програмою стимулює розвиток соціального інтелекту, як основи для надбання соціальної компетентності, дозволяє отримати позитивні результати в напрямку соціалізації та адаптації майбутнього покоління, зокрема:

- здобуваються навички структурності при обробці отриманої інформації, іï диференційований відбір;

- з’являється об'єктивність в оцінюванні (себе, людей, ситуацій, подій);

- збільшується ступінь адекватності дій, через усвідомлення причиннонаслідкових взаємозв'язків подій;

- усвідомлюється поняття межі: для розуміння і оцінювання співіснування соціальних структур, необхідно знати межі кожної з них; 
- складається логічна картина існування світу і місце окремих структур, їх ієрархічність та їх взаємопов'язаність, місце і роль окремих людей в кожній 3 них;

• відпрацьовуються комунікативні навички;

- виробляється звичка до співпраці, якій надається перевага (перед конкуренцією), як діяльності, що з мінімальними енергетичними витратами дозволяє досягнути результатів;

- конкуренція усвідомлюється як засіб отримання альтернативної точки зору, для підвищення власних досягнень, поінформованості та знаходження нових шляхів і способів діяльності.

Все це являється основою успішного включення особистості в соціальні структури і дає можливості для вирішення нею проблем як матеріального так і морального характеру.

Висновки. Застосування програми дозволяє підвищити навчальний інтерес учнів, а відтак і якість їх знань, вмінь, навичок, які вони здобуватимуть в процесі навчальної діяльності. Спільна робота, опанування основ тематичної дискусії з дотриманням етичних норм, сприяє підвищенню рівня вихованості дітей, їх емпатійності, позитивній комунікативності, адекватному сприйнятті оточуючих, як однолітків, так і представників інших вікових груп, що в свою чергу дозволяє прискорити процес адаптації до нових умов та вміння співпрацювати.

\section{Список використаних джерел}

1. Віденко В. Ф. Людина і світ / В.Ф. Віденко, Л. В. Віденко, В. І. Кондратова-Діденко.- К. : Вища школа, 2001. - 229 с. 
2. Архіпова С. П. Професійна компетентність і професійність соціального працівника: сутність і шляхи розвитку / С. П. Архіпова //Соціальна робота в Україні: теорія і практика. - 2004. - №2.

3. Гарашкіна Н. Діагностика професійної компетентності / Н. Гарашкіна // Соціальна педагогіка. - 2003. - № 4.

4. Гіндіна О. Д. Генетичні основи емоцій та поведінкових особливостей у дітей підліткового віку / О. Д. Гіндіна. - М., 2005 - 24c.

5. Дементьєва I. Ступінь соціальної відповідальності підлітків у повній та неповній родині /Дементьєва І., Зубарева Н.//Виховання школярів.- 2003. - № 10.

6. Докторович М. О. Формування соціальної компетентності старшого підлітка з неповної сім’ї: дис. канд. пед. наук - Київ, 2007.

7. Життєва компетентність особистості: наук.-метод. посібн. [ред. Л. В. Сохань, І. Срмаков Г., Несен Г. М.].- К.: Богдана, 2003. - 520 с.

8. Лєпіхова Л. Соціально-психологічна компетентність у педагогічній взаємодії. // Вища освіта України. - 2004. - №3.

9. Мельник О. I. Зміст комунікативної компетентності педагога / O. I. Мельник // Психологія і школа. - 2004. - № 4.

10. Поздняков А. Готуємо вчителя до формування соціальної зрілості старшокласників. //Учитель. - 2003. - №4.

11. Реан А. А. Психологія підлітка / Реан А.А.- М.: Олма-прес, 2003.-432c.

12. Толстих Т. І. Становлення соціальної зрілості учнів юнацького віку в умовах проектної діяльності / Т. І. Толстих // Психологія і школа.- 2004.- № 4.

\section{References}

1. Videnko, V. F. Videnko, L. V., Konfratova-Didenko, V. I. (2001), Lyudyna i svit [Man and the world], Higher school, Kyiv, Uk. 
2. Arkhipova, S. P. (2003), "Professional competence and professionalism of a social worker: the essence and ways of development", Sotsial'na robota v Ukrayini: teoriya i praktyka, vol.2, Uk..

3. Garashkina, N. (2003), "Diagnosis of professional competence", Sotsial'na pedahohika, vol. 4, Uk.

4. Gindina, O. D. (2005), Henetychni osnovy emotsiy ta povedinkovykh osoblyvostey $u$ ditey pidlitkovoho viku [Genetic bases of emotions and behavioral features in adolescents], Moscow, Ru.

5. Dementieva, I. Zubareva, N. (2003), "The degree of social responsibility of adolescents in complete and incomplete families", Vospitaniye shkolnikov, vol. 10, $\mathrm{Ru}$.

6. Doktorovich, M. O. (2007), Formuvannya sotsial'noyi kompetentnosti starshoho pidlitka z nepovnoyi sim"yi [Formation of social competence of the senior teenager from a single-parent family], Kyiv,Uk.

7. Sokhan, L. V. Yermakov, I. Nesen, G. M. (2003), “Zhyttyeva kompetentnist' osobystosti: nauk.-metod. posibn." [Life competence of the individual: scientific method. manual],Bogdana,Kyiv, Uk.

8. Lepikhova, L. (2004), "Socio-psychological competence in pedagogical interaction", Vyshcha osvita Ukrayiny, vol. 3, Uk.

9. Melnyk, O. I. (2004), "The content of communicative competence of the teacher", Psykholohiya i shkola, vol.4, Ru.

10. Pozdnyakov, A. (2003), "We prepare teachers for the formation of social maturity of high school students", Uchytel, vol. 4, Ru.

11. Rean, A. A. (2003), Psykholohiya podrostka [Psychology of adolescents] / Olma-press, Moscow, Ru.

12. Tolstykh, T. I. (2004), "Formation of social maturity of young students in terms of project activity", Psykholohiya i shkola, vol.4, Ru. 